\title{
Levirate marriage amongst the Hebrews and widow's inheritance amongst the Yoruba: A comparative investigation
}

\author{
Authors: \\ Samson O. Olanisebe \\ Olusegun A. Oladosu ${ }^{1}$ \\ Affiliations: \\ ${ }^{1}$ Department of Religious \\ Studies, Obafemi Awolowo \\ University, Nigeria \\ Correspondence to: \\ Samson Olanisebe \\ Email: \\ soolanisebe@yahoo.com \\ Postal address: \\ Department of Religious \\ Studies, Obafemi Awolowo \\ University, Ile-Ife 220005, \\ Nigeria \\ Dates: \\ Received: 16 Jan. 2013 \\ Accepted: 28 Nov. 2013 \\ Published: 24 Mar. 2014 \\ How to cite this article: \\ Olanisebe, S.O. \& Oladosu, \\ O.A., 2014, 'Levirate \\ marriage amongst the \\ Hebrews and widow's \\ inheritance amongst the \\ Yoruba: A comparative \\ investigation', Verbum et \\ Ecclesia 35(1), Art. \#826, \\ 7 pages. http://dx.doi. \\ org/10.4102/ve.v35i1.826

\section{Copyright:} \\ C 2014. The Authors. \\ Licensee: AOSIS \\ OpenJournals. This work \\ is licensed under the \\ Creative Commons \\ Attribution License.
}

Read online:
In ancient Israel, even though widowhood was not something people were praying for, when it came, the people involved were protected by the legal and customary structures already in place. One of those structures in the Old Testament is the institution of the levirate marriage where the right and the possession due to a widow without a son for her late husband could be protected and appropriated. A similar custom was also found amongst the pre-colonial Yoruba people through the widow's inheritance which guarantees the welfare of the widow after the demise of her husband. However, these structures have been dismantled by Christianity, thereby exposing the majority of present-day widows to untold hardship. This article, therefore, through historical, descriptive and comparative methods, examines the customs of the levirate marriage and widow's inheritance in the two cultures, ascertains how effective they were in addressing the welfare and protection of the rights and privileges of widows and recommends how the church can better see to the welfare of the widows in the society.

\section{Introduction}

The widows in present-day Nigeria are amongst the groups of people that have not been adequately catered for, both at the family and societal levels. Betty Potash has given the statistics that widows constitute a quarter of the adult female population in many African communities, and yet systematic investigation about them is missing (Potash 1986:1). Fasoranti and Aruna (n.d.:54) also believe that the absence of diachronic studies aimed at showing how widowhood practices have evolved or changed over time, especially as a result of religion, worsens the situation. Many of the widows could be described as victims of circumstances after the demise of their husbands. Ejizu (1989:174) describes how many of these widows have been further exposed to a series of bizarre experiences with the attendant embarrassment and aggravation of distress after the misfortune of losing their husbands. Many have been denied the benefits of their matrimonial home, and their human rights have been subjugated by their husbands' families. As a result, they have been dehumanised and subjected to many untold hardships. For those whose children are still young, many of the children have dropped out of school and have become victims of child labour and child trafficking. There is no adequate facility put in place to take care of the widows and their children in society, either by the relatives of the deceased husband or by the government. However, amongst the Jews and the traditional Yoruba, measures were put in place to take care of the widows through the widow's inheritance that has been displaced by Christianity and modernity today. This article, therefore, seeks to examine the levirate marriage amongst the Jews and widow's inheritance amongst the traditional Yoruba people with the aim of bringing out the purpose of such 'marriage' system, the change that has been brought to it by modernity and the roles that families, the Church and government can play in assuaging the plights of the widows in Nigeria.

The article makes use of a multi-disciplinary approach. Historical and narrative approaches and methods of analysis are used because of the inter-disciplinary nature of the article. The historical method is used by retrospectively narrating how what can be termed as 'widow's inheritance' was being consummated amongst both the Jews and the traditional Yoruba. This understanding of the past will in turn assist to address the present realities on the issues of widowhood. This fact is corroborated by Satlow when he says that 'a scholarly study of the past (can) contribute to burning contemporary societal issues' (Satlow n.d.). Next a comparative analysis of the customs in the two cultures is carried out with a view to show that the customs provided for the social, physical, material and emotional needs of the people and that even though it has been displaced by Christianity, the Church should provide a better and effective way of catering for the welfare of widows. 


\section{Levirate marriage amongst the Jews: The process and the people involved}

The term 'levirate marriage' (yibbum) in the Old Testament is the custom of a widow (yevamah) marrying her deceased husband's brother or sometimes a near kin. The word 'levirate' has nothing to do with the name Levi or the biblical Levites but is derives from the Latin levir, meaning husband's brother, connected with the English suffix ate, thus constituting levirate (Levirate Marriage n.d.). The description of the custom is first seen in Genesis 38 in the story of Judah, his sons and Tamar. It is to be noted that scholars have put forward the various purposes of the story of Judah and Tamar in Genesis 38 where the issue of levirate marriage was first documented. Whilst some believe that the story is connected with the legitimation of David's claim to the throne, others believe that it portrays the intermarriage between the tribe of Judah and Tamar who was a Canaanite. Emerton (1975:344, 1979:403-408) again believes it to be a story about individuals, a story which contains aetiological motifs concerned with the eponymous ancestors of the clan of Judah and reflects a period when members of the tribe were living alongside Canaanites and intermarrying with them. Friedman sees the story as a folklore attributing demonic forces of death to women. He opines that the etymology of Eve may be from a word meaning snake and that, if that etymology is correct, the story of Tamar in Genesis 38 may be assumed to contain an older folk stratum in which primeval woman herself was associated with the serpent, the symbol of Satan and death (Friedman 1990:25). Concerning the question why the chapter interrupts the Joseph narrative, Hayes (1995:81), whilst discussing various interpretations giving to Judah's confession that Tamar was more righteous than himself, is of the opinion that it is likely that the chapter was inserted to demonstrate the humiliation of Judah, which is seen either as a punishment for his role in the selling of Joseph or for not marrying Shelah and Tamar. In a recent article, Leuchter posits that the literary form of Genesis 38 may have resulted from a scribe writing with an eye to the larger Joseph story, but this scribe's handling of the Judah-Tamar episode points to its origins beyond the sources that constitute the tale of Joseph and his brothers. He believes that, if this was the case, the thematic commonalities may be attributed to a common set of cultural tropes behind each work rather than a single story built from the ground up. He also identify the likely relationship between Genesis 38 and the Tamar-Amnon drama of 2 Samuel 13 since these are the only narratives in the Hebrew Bible where a character named Tamar plays a major role (Leuchter 2013:212). Niditch sees the levirate story in Genesis 38 as a depiction of the place of women in Israel's social structure. To him, a married woman who bears children is to be under the protection of her husband. The unmarried young virgin is to remain under the protection of her father's house except in the case of rape in which the man is expected to marry her to save the girl from becoming a social misfit. But a married, childless widow is considered a social misfit in the society and this may be the reason why the levirate system is put in place so as to save the woman from shame and to ensure her protection. According to Niditch (1979:146), Judah's attempt to send Tamar back to her father's house is highly irregular in Israelite's social structure because she no longer belongs there.

Apart from the Genesis narrative on the levirate, the custom seems to be normative amongst the Jews because it is one of the commands given to the bene yisrael [sons of Israel] by Moses during his valedictory speech in Deuteronomy 25:5-10. He instructed them that, if one of the brothers that are living together dies without having a son, the brother of the deceased should marry the woman and raise a son for the deceased brother. This means the first son of the marriage belongs to the deceased.

However, the brother of the deceased is not under any compulsion to agree to this kind of marital arrangement. He has the option of rejecting the arrangement for reason(s) best known to him, which may be selfish as suggested by Davies (1981a:258-259). If he opted out, it is expected that the wife make this decision known to the elders, and she is expected to remove the sandal of her deceased husband's brother and spit into his face in public and before the elders of the land (Dt 25:9; cf. Rt 4:1-12). In trying to know the importance or symbolism of the act of removing the shoe of the levir, Carmichael (1977:322-323) has put forward the opinions of Gaster and Levy to the effect that shoe removal is an Arab form of divorce in which the man sometimes removes his shoe and states: 'She was my slipper; I have cast her off.' In Arabic, a wife is sometimes figuratively referred to as a 'shoe'. Also in almost universal folk usage, Levy pointed out the erotic significance of the foot as a male symbol and the sandal as a female symbol. The man's renunciation of the woman causes her to withdraw symbolically from him by removing his shoe. She thereby breaks off the potential marital relationship. He no longer has any right to her, and she is now free to marry another (Carmichael 1977:323). Furthermore, Carmichael has seen the ceremony of the removal of the sandal as analogous to the Genesis narrative of the relationship between Onan and Tamar. He suggested that, just as the removal of the sandal from the feet of the levir who refused to perform his duty signifies the man's withholding of conception (since amongst the Arabs the sandal symbolises female genitals and amongst the Hebrew feet symbolises the male organ), the spitting in his face also represents Onan's spilling of the semen on the ground. This is meant to bring disgrace to the man (Carmichael 1977:329-331) and possibly accusing him of being impotent (Miller n.d.). The man then acquires an appellation, in addition to whatever name he bears: 'The house of him who has his sandal removed' (Dt 25:10). This phrase did not only have negative implications for the man himself, but it extended to his household and generation because the appellation became the terms of reference not only to his immediate family but to the upcoming generation. The negative appellation can be described as pointing to the uncaring attitude of the levirate brother. At the end of this opting out process, an official written permission, known as halitzah, is issued to the woman to marry whoever she wants, 
except the priest. Until she was granted this leave, she was required to enter into a marriage with the brother of her departed husband only (The Shepherd 2000). Halitzah can be chosen by one or both of the parties in order to become free of the duty to marry one another (The New Encyclopedia of Judaism n.d.).

It is to be noted that the marriage between Ruth and Boaz has been seen and interpreted by some scholars in the light of re-enacting the levirate marriage whilst others do not agree with that position. For instance, Siquans (2009:451-452) has shown how Ruth, a foreigner (non-Israelite, being a Moabite, whom Yahweh proscribed from entering into the synagogue in Deuteronomy 23:4-5) and a widow, made use of the legislation in the Torah as regards Israelites' responsibility to care for the foreigner and of the levirate marriage in order to become an integrated member of the Judaean society. Beattie, in contrast, does not see any trace of the levirate marriage in the book of Ruth but the possibility for widows to inherit their husbands' property. To him, since it is impossible for a storyteller to describe what is not known amongst the people, the fact that the author represents Naomi as being in possession of her husband's property must serve as an indication that it was possible in Israelite law for widow's to inherit her husband's estate (Beattie 1974:256).

The levirate is a specific law for a specific situation. In Scripture, it is found that the patriarchs practiced it, Moses commanded it and the Jews may well have practiced it in the time of Jesus because the Jews referred to it when testing Jesus in Matthew 22:23ff. (Muldoon n.d.). Commenting on the function or usefulness of levirate marriage on the family, Weisberg (2008:77), is of the opinion that marriage marks the beginning of a new family unit and/or the expansion or blending of existing families. The levirate marriage, in contrast, comes into play when a family experiences the loss of a member. As such, the levirate offers an opportunity to study the family at a moment of breakdown and restructuring and also offer an attempt to mend that which had been broken, reconstituting one part of a family by rearranging its members and realigning their relationship to each other. However, in Weisberg view, the rabbis' unique construct of the levirate results in the creation of an entirely new family rather than reforming the one broken by the husband's death because an individual man or woman's primary obligations should be to an existing spouse rather than to the extended family, as represented by a deceased spouse or sibling (Hebrew Union College-Jewish Institute of Religion 2009:77-78).

\section{The purpose of the levirate marriage amongst the Hebrews}

The purpose of the levirate is to ensure that the lineage of a man who dies without being able to produce an heir would not die out. This concern for ensuring the continuation of the lineage of the deceased is understandable for in Israel it was regarded as a great misfortune for a man to die without male issue. This accounts for people turning to polygamy, adoption and other methods in the bid to have a male child (Davies 1981b:140). This preservation of a man's 'name', according to Burrows (1940:2), involved at least three things. It involved the provision of an heir for his property so that it might be kept in the family and in the normal line of inheritance. It involved also the continuation of his personal life in the life of his son according to a deep-seated conception of the ancient world. To this may be added the idea of welfare in the hereafter as dependent upon the performance of ancestral rites by the descendants. For a man who left no son, there would be nobody on earth to perform these rites. The firstborn son of a levirate marriage would be reckoned as the heir of the deceased brother. It is true that happiness for the ancients would not have been complete without the birth of a son (Bewes 1903-1904:202-206). In the story of Judah and Tamar, however, Onan was not favourably disposed to such an arrangement probably because he wanted to keep the firstborn portion of the inheritance for himself (Wilson n.d.).

Porter has seen the levirate marriage as an example of the principle of corporate personality enshrines in the Old Testament whereby family, clan and tribe are treated as a unit rather than individuals, hence the taking over of the deceased widow by the brother in the family (Porter 1965:379). The marriage can still be seen as a device by God to ensure proper caring for the widow. Reading through the Old Testament, one discovers that, though the land of Israel is described as a land flowing with milk and honey, not all inhabitants possessed land to have access to its benefits. The biblical text mentions certain classes of vulnerable people in the land, which include sojourners, widows, orphans, slaves and hired servants. There are many biblical laws that stipulate how these people should be treated with justice and fairness, and there are laws on how they should be cared for. Hiers (2002:64) enumerates some of those biblical laws. For instance, the condemnation of the oppression of widows and orphans is expressed in Exodus 22:22-24 where it is stated:

You shall not afflict any widow or orphan. If you do afflict them and cry to me, I will surely hear their cry, and my wrath will burn, and I will kill you with the sword, and your wives shall become widows and your children fatherless.

One such piece of legislation is the levirate marriage, which is a loose piece of legislation that allows the relevant person the freedom to accept or reject the responsibility stipulated in the law with no stringent penalty except the negative appellation attached to the man who rejects the marital arrangement.

Burrows (1940:7) also identifies as part of the reasons or purposes of the levirate marriage amongst the Hebrew the fact that the widow may be kept in her husband's family so as to take care of her husband's children, administer his property, getting value for her labour in her husband's house and the necessity of making some provision for her support. This is because in some of the cultures of ancient Near East, such as Babylonia, Hittites and Assyria, provision was made for the widow to inherit her deceased husband's property. Such provision was not made in Israel, especially if the widow was childless (Davies 1981b:138-139). 
The injunction on the levirate marriage raises a number of questions. For instance, it states that the levirate marriage is allowed in a situation where the brothers dwelt together, and the deceased did not have a son. The questions then are: Did the Hebrew word translated 'son' stand for any child or male child? What if the deceased had already had daughters, are they not children? Does it matter whether the levirate brother has already married his own wife or not? Should the brother of the deceased be younger or older? Is it only blood brothers of the same parents that is qualified to marry the widow, or anyone within the family circle?

Scholars are sharply divided as to the meaning of the phrase 'dwelling together' in Deuteronomy 25:5. Some of these views have been put together by Leggett. For instance, whilst Driver and Miles (in Leggett 1974:44-46) see the phrase to mean brothers who have not divided the inheritance after their father's death, which would indicate their living on a joint estate, Neufeld (in Leggett 1974:44-46) sees the law as a trace of an ancient custom of Hebrew family law which was no doubt out of date in Deuteronomic times. Daube (in Leggett 1974:44-46) argues convincingly that the phrase, as conceived by its author, dealt with a consortium where brothers remained together on the paternal estate after their father's death. Daube believes that, in this case, if one dies without leaving children and the survivor refused to raise seed for him in order that his place in the consortium should be filled again, the widow could summon the traitor before the elders (Leggett 1974:44-46). For Belkin, it must be blood brothers who have equal rights in the inheritance. This invariably meant that a brother from the maternal side is not permitted to fulfil the levirate since he has no right to paternal inheritance (Belkin 1970:281). It can, however, also be the next of kin or a near kinsman or a covenant brother as in the case of Boaz in the levirate marriage of Ruth (Fisch 1982:430-431).

In the Hebrew language, there are different words for son (ben) and daughter $\left(b a^{\prime} t\right)$. If the writer had male and female in mind, he would have used both words. In Deuteronomy 25:5, however, the writer used the word ben, which indicates that he is referring to a male child. In another vein, the writer might have been influenced by the Jewish culture which did not give much recognition to women or female children. This suggests the importance attached to male children amongst the Hebrew. This argument, however, raises gender issues such as whether male children are better than or more superior to female children. It confirms one of the purposes of the levirate marriage, which is to maintain the deceased man's name. Maintaining the name included maintaining his inheritance rights since female children were not entitled to inherit their fathers' property (Nwaoru 2002:86-88).

The position of the brother-in-law, whether he should be a younger or older brother, is not specified. The most important requirement is that he should be related to the deceased by blood. In addition, his marital status, whether single or married, does not matter. As a matter of fact, the levirate brother is required to take up his brother's widow regardless of his marital status (The Shepherd 2000). There are many examples of these kind of marriage in the Old Testament. The first case mentioned in Genesis 38 is the case of Judah's three sons. Though some scholars regard the marriage of Ruth to Boaz as a levirate marriage, Hubbard (1991:4-5) disagrees with that position and portrays their relationship as marriage of $g^{e} u l l a$ or redemption by a kinsman-redeemer or a close relative who takes upon himself the duties of redemption or recovery on behalf of a needy family member. Belkin also believes the marriage of Ruth and Boaz to be an agnate marriage (marriages within the family) and not a levirate marriage because neither the go'el nor Boaz was brothers of the deceased. They seemed to have been only kinsmen (Belkin 1970:277, 284).

\section{Widows' inheritance amongst the Yoruba}

In Yoruba parlance, inheritance has different meanings. It is considered as property left behind for the heirs, wife and agnatic relatives of the family (Babatunde 1982:69-86). To Lloyd (1959:7), inheritance should not be seen only as the entrance of living persons into the possessions of dead persons, nor should it be seen as a succession to all rights of the deceased. Rather, it is to be considered as the transference of the status from the dead to the living with respect to specific property objects. The meaning of inheritance (ogun jije) considered the word 'Ohun gigun', which indicates that the property left behind by the deceased must not be left alone too long to allow it to disintegrate in quality and use. In this case, the property must be distributed to enhance its quality. In another dimension, 'Ohun gigun' connotes the sweat induced by the labour of the deceased during his life time (oogun) through which he acquired property. This then portends that it is the property acquired by the deceased through hard labour that are now shared as inheritance after his death.

The property to be shared ranges from farmland, houses, material property land property and the widow of the deceased. The most intriguing thing amongst the Yoruba is that the wife of the deceased was not allowed to share in the property as she herself must be inherited even though she contributed so much to production in the agricultural economy of the Yoruba traditional society. As a matter of fact, it has been discovered that $45 \%$ of women in African societies as a whole and $53 \%$ in sub-Saharan African play a major part in the cultivation of pastures as well as in purely farming economies (Goody \& Buckley 1973:108). This formula for sharing inheritance is not unconnected to the tradition of people that puts the legal provisions for the widows at the discretion of men and makes men to be the determinant of who shares what from his inheritance (Okeke 2000:55). Those who have the advantage of sharing from the inheritance are the extended male member of the deceased and the children of the deceased, in some cases.

Adeoye (2003:33) asserts that widows are shared like the property of the dead. Struensee (n.d.) also confirms that widows are regarded as chattel being inherited like other 
possessions. These assertions are true amongst the Yoruba who consider widows part of the deceased inheritance that must be shared alongside the material property. The concept of widowhood is a double-edged phenomenon. The first has to do with a bereaved woman who is in deep mourning of her husband. This in Yoruba parlance is noted to be opo sise [mourning]. The second nomenclature is opo sisu [widow's inheritance or remarriage]. This is the means by which a younger wife of the deceased is handed over to another man for proper care. Such a man must come from the same family of the dead husband. This practice follows the sayings amongst the Yoruba that adie ki ku ka da eyin re nu [the death of a hen should not warrant the disposal of its egg], indicating that proper care must be given to the belongings of the deceased, both human and material. This form of marriage system amongst the traditional Yoruba usually surfaced when young ladies were given in marriage to very old men who died shortly after, leaving the young ladies widowed. According to Ademiluka, whilst recounting the confrontation of the Christian Missionary with the culture and customs of the Yoruba, he emphasised that such a young widow, in an attempt to raise up children for the barren deceased or just to remain in the family of her deceased husband, would be inherited by a young man, a member of the family of the deceased, who would raise children for the deceased (Ademiluka 2003:138). Whilst discussing the role of women in marriage and family life in the pre-colonial Yorubaland and connecting it to Opo Sisu, Denzer (1994:3) is of the opinion that a wife's responsibilities to the family into which she married lasted for her entire lifetime, extending beyond the death of her original husband, for if he died, she was inherited by one of his brothers or sons but definitely not by her own son.

After the death of her husband, the widow goes through the mourning period to sever the bond between her and her dead husband (Adeyefa n.d.). The period of mourning is about 3 months during which the widows must stay indoors to observe the mourning rites. They are not allowed to do anything that will take them out, but they have to keep themselves occupied with domestic work. They are not allowed to have any personal attention, bathing, doing their hair or change the cloth they had on during the time of the death of their husband (Johnson [1921] 2001:115). According to Aransiola and Ige (2010), widowhood practices amongst the Yoruba is performed for various reasons such as the protection of the woman from being harmed by the spirit of her dead husband, to prove the innocence of the woman as regards the death of the husband and for the family to ascertain if the woman has been pregnant before the death of her husband so that they may claim responsibility for the pregnancy.

After the mourning, the widow who is qualified for remarriage within the family would be allowed to choose one of the younger brothers of her deceased husband. There are some criteria that the widow must meet before being allowed to re-marry. These include the fact that she must be young and active for procreation, she must not have been found active in any amoral acts and she should not have been having illicit affairs before the death of her husband. The brother that is to marry the widow must also meet certain criteria such as the fact that he must be of the same family of the dead person, he must be younger than the dead husband, the relationship with the dead husband must have been cordial whilst the latter was alive, there must not have been any reported case of an illicit affair with the widow before her husband's death and he must not have been found to have any connection with the death of his brother.

Before the day agreed upon for the choice of the new husband by the widow, the men from the deceased's family who qualified would have been going to make their intentions known to the widow. On the agreed day, place and time, various items belonging to all the contestants would be brought. The widow would be allowed to choose or point to only one of the many items to be presented on behalf of many contestants amongst the men in the family. Pointing to any of the items shows that she knows the person very well. This is also done to avoid enmity amongst the contestants in the family. Materials or items that were usually used to determine the widow's choice included chewing sticks, head caps and shoes of different contestants. Any of these materials could be used to determine the would-be husband.

The issue of widow's inheritance or remarriage is a decision which, in Yorubaland, belongs solely to the woman. The woman may decide to accept or reject the position of taking another husband. Old women are not allowed to take another husband even if they are yet to give birth to children for their deceased husbands, but preparations are made for their care. It is to be noted that a widow cannot undergo these processes twice. Where there are several women, the heir who succeeds to the headship of the house usually inherits the majority of the women. The woman is expected to decline an offer once or twice, but if rejected the third time, the refusal is taken as final (Johnson [1921] 2001:115-116). It must be stressed that the purpose of widow's inheritance amongst the Yoruba is primarily to ensure the welfare of the widow within the family because the woman is regarded as an inheritance of the deceased and must be taken good care of in the absence of the deceased. The aim is not necessarily to raise up children for the deceased.

\section{Comparative analysis of levirate marriage and widow's inheritance in the Hebrew and Yoruba cultures}

Having seen the meaning, processes and purpose of the levirate marriage amongst the Hebrew and widow's inheritance amongst the Yoruba, it seems that the two customs have certain peculiar features whilst not denying the obvious divergences. The two customs are similar in that both are types of re-marriage of the widow within the deceased husband's family after the death of the first husband. Both are connected to perpetuating the inheritance of the deceased husband. In both cultures, women are not allowed to inherit 
their husbands' property. The property is rather given to the children. Even if the children are under age, amongst the Yoruba, a male member of the family is chosen to hold the property in trust for the children until they are mature enough to handle it. The children, in turn, may then give whatever they deem fit to the mother. This provision does not exist amongst the Hebrews, and it might have warranted the devise of the levirate marriage so as to be able to give the woman the opportunity for sustenance and support from the husband's property. It may even have allowed for the exceptional permission granted by Yahweh to the daughters of Zelophehad in Number 27:1-11 to inherit their father's property in the absence of a male son (Carmichael 2008:232-233). The case of the daughters of Zelophehad is, however, an exception because it involves the inheritance of their father and their deceased husbands. Both traditions are similar in the way they see and treat women. Amongst the Yoruba, women are considered part of the property to be inherited. The will, in most cultures, also provides ample evidence that a woman has no independent legal status but was treated as the personal property first of her father and then of her husband (Phillips 1973:351).

In addition, in both cultures, the process is to be supervised by the elders in the family, and both give the widow the opportunity to remain within the family circle of her late husband. It must be noted that the two cultures attach great importance to procreation. If a woman does not give birth to a child, she is not counted as a full member of her husband's family (Niditch 1979:144-145). The levirate marriage and widow's inheritance, therefore, give the widow the opportunity to stay within her husband's family and give birth either in honour of her husband or to prove her fertility to the people. Furthermore, the two customs have almost, if not completely, faded out in the two cultures as a result of the challenge of Christianity, Western education, civilisation, modernity (Oladosu 2008:77-78), economy and change in gender role and status orientation and awareness.

However, in spite of these similarities, the two customs also exudes certain distinctive differences. These include the fact that the primary purpose differs. For instance, whilst procreation of a male child to continue the name of the deceased is the primary purpose of the levirate marriage, the welfare of the widow is the primary purpose of widow's inheritance. The two cultures attach great importance to the continuity of a lineage through male children. It is believed that, when a woman gets married, the cultural norm demands that she drops her father's name to take up the family name of her husband thereby increasing the numerical growth of her husband's family. However, amongst the Yoruba, a widow does not necessarily have to be childless before she is asked to re-marry in the family. In the Hebrew culture, the welfare of the widow is also part of the secondary purpose of levirate marriage.

In addition, whilst the relationship between the levir and the deceased is not clearly stated in the levirate law, the levir must necessarily be a younger brother or son of the deceased amongst the Yoruba. Furthermore, whilst there is the ceremony of the removal of the sandal in the levirate marriage to shame the man who refuses to take up the duty of perpetuating the name of his deceased brother, in Yoruba culture, it is the woman who determines whether she wants to be re-married and who she is going to marry amongst the younger brothers of her deceased husband. This implies that there is usually a competition amongst the younger brothers of the deceased about who is going to marry the widow because they know that whoever marries the widow automatically inherits the deceased property. Such competition is alien in the levirate prescription because the levir knows that his rejection of the levirate marriage puts him in a better position to take over the deceased portion of the inheritance in their father's property.

\section{Conclusion}

In spite of the discernible differences pointed to above in the two customs, the purpose of this article was to show how the levirate marriage and widow's inheritance have been used in the two cultures under consideration as welfare scheme for the widows. It is a fact that widow's inheritance amongst the Yoruba has been displaced by Christianity and some other immediate and remote factors. However, the questions remain: How effective is the welfare scheme that is put in place for the widows by the church? Is the occasional extension of a good-will gift by the church really addressing the needs of the widows? If a welfare scheme is objected against and cancelled, one at least expects a better one as replacement. The fact of the matter is that larger percentage of the widows in Africa in general and Nigeria in particular are still experiencing the harrowing effect of widowhood. Whilst not advocating a return to the levirate marriage and widow's inheritance amongst Africans as a means of solving the problems of dehumanisation, deprivation, dispossession and disempowerment of widows, a clarion call is been sent to the church to revisit her welfare and empowerment programmes for the widows and come up with more practical and effective means of addressing the widowhood challenge in Africa, especially for widows, both old and young, who are childless or whose children are still too young to be able to take adequate care of them. Whilst not demeaning the efforts of the church and other non-governmental organisations (NGOs) in battling with the eradication of the dehumanising widowhood rites in many of the African countries (Adamu et al. 2011), the adequate social and economic welfare of widows must not be divorced from or neglected in the campaign. It is the church that is best positioned to also help, through the re-engineering of the societal norms and value systems and the need to be our brother's keeper, to fight various degrees of injustice that are being meted out to widows.

\section{Acknowledgements Competing interests}

The authors declare that they have no financial or personal relationship(s) that have inappropriately influenced them in writing this article. 


\section{Authors' contributions}

S.O.O. (Obafemi Awolowo University) was the initiator of the article. He formulated the abstract, wrote the introduction and the section on levirate marriage in the Old Testament. $\mathrm{He}$ also did the comparative section and conclusion. O.A.O. (Obafemi Awolowo University) wrote the section on widow's inheritance amongst the Yoruba and also wrote part of the comparative analysis.

\section{References}

Adamu, F., Ajala, A.O., Para-Mallam, O.J. \& Lanre-Abass, B., 2011, 'Engagements of women's movements with religion: Legal reform in Anambra State, Nigeria', in Religion and Development Research Programme, Working Paper 60, p. 2, viewed 10 December 2012, from http://www.rad bham ac.uk

Ademiluka, S.O., 2003, 'The impact of Christian missionary activity on the sociocultural heritage of the O-kun Yoruba', in A. Olukoju, Z.O. Apata \& O. Akinwunm (eds.), Northeast Yorubaland: Studies in the history and culture of a frontier zone, pp. 134-142, Rex Charles, Ibadan.

Adeoye, A.A., 2003, Itopinpin Orirun Asa Pelu Agbeyewo Awon Isembaye, Immaculate City, Oyo.

Adeyefa, T., n.d., Widowhood: A life gone miserable?, viewed 10 December 2012, from http://businessdayonline.com/NG/index.php/family/15862-widowhood-a-lifegone-miserable

Aransiola, J.O. \& Ige, A., 2010, 'Widowhood practices among the Yorubas of South West Nigeria: Are there differences in what women experience due to their status?', in Gender and Behaviour, viewed 11 December 2012, from http://www. status?', in Gender and Behaviour, viewed 11 Dec

Babatunde, O., 1982, 'Asa Isinku ati Ogun Jije', in O. Olajubu (ed.), Iwe Asa Ibile Yoruba, Longman, Lagos.

Beattie, D.R.G., 1974, 'The book of Ruth as evidence for Israelite legal practice', Vetus Testamentum 24(3), 251-267.

Belkin, S., 1970, 'Levirate and agnate marriage in rabbinic and cognate literature', The Jewish Quarterly Review, New Series 60(4), 275-329.

Bewes, J.A., 1903-1904, 'The goel in Ruth 4:14-15', American Journal of Semitic Languages and Literature 20, 202-206.

Burrows, M., 1940, 'The ancient oriental background of Hebrew levirate marriage', Bulletin of the American Schools of Oriental Research 77, 2-15. http://dx.doi. org/10.2307/1355235

Carmichael, C.M., 1977, 'A ceremonial crux: Removing a man's sandal as a female gesture of contempt', Journal of Biblical Literature 96(3), 321-336. http://dx.doi. org $/ 10.2307 / 3266188$

Carmichael, C., 2008, 'Inheritance in Biblical sources', Law and Literature 20(2), 229-242. http://dx.doi.org/10.1525/lal.2008.20.2.229

Davies, E.W., 1981a, 'Inheritance rights and the Hebrew levirate marriage: Part 1', Vetus Testamentum 31(2), 138-144.

Davies, E.W., 1981b, 'Inheritance rights and the Hebrew levirate marriage: Part 2', Vetus Testamentum 31(3), 257-268.

Denzer, L., 1994, 'Yoruba women: A historiographical study', The International Journal of African Historical Studies 27(1), 1-39. http://dx.doi.org/10.2307/220968

Ejizu, C.I., 1989, 'African Christian widows: An agnostic definition', Asia Journal of Theology $3(1), 174-183$

Emerton, J.A., 1975, 'Some problems in Genesis XXXVIII', Vetus Testamentum 25(2a), 338-361.

Emerton, J.A., 1979, 'Judah and Tamar', Vetus Testamentum 29(4), 403-415.

Hebrew Union College-Jewish Institute of Religion (HUC-JIR), 2009, Excerpts of new books, viewed 10 December 2012, from legacy.huc.edu/chronicle/71/flipbookk/ files/assets/basic-html/page

Fasoranti, O.O. \& Aruna, J.O., n.d., 'A cross-cultural comparison of practices relating to widowhood and widow inheritance among the Igbo and Yoruba in Nigeria', Journal of World Anthropology: Occasional Paper III(1), 53-73.
Fisch, H., 1982, 'Ruth and the structure of covenant history', Vetus Testamentum 32(4), 425-437.

Friedman, M.A., 1990, 'Tamar, A symbol of life: The "killer wife" superstition in the Bible and Jewish tradition', Association for Jewish Studies Review 15(1), 23-61. http:// dx.doi.org/10.1017/S0364009400002804

Goody, J. \& Buckley, J., 1973, 'Inheritance and women's labour in Africa', Journal of the International African Institute 43(2), 108-121. http://dx.doi.org/10.2307/1159323

Hayes, C.E., 1995, 'The midrashic career of the confession of Judah (Genesis XXXVIII 26), Part I: The extra-canonical texts, targums and other versions', Vetus Testamentum 45(1), 62-81.

Hiers, R.H., 2002, 'Biblical social welfare legislation: Protected classes and provisions for persons in need', Journal of Law and Religion 17(1/2), 49-96. http://dx.doi. org/10.2307/1051395

Hubbard, Jnr., R.L., 1991، 'The go'el in Ancient Israel: Theological reflections on an Israelite institution', Bulletin for Biblical Research 1, 3-19.

Johnson, S., [1921] 2001, The history of the Yorubas, CSS, Lagos.

Leggett, D.A., 1974, The levirate and goel institutions in the Old Testament, Mack Publishing, Cherry Hill.

Leuchter, M., 2013, 'Genesis 38 in social and historical perspective', Journal of Biblical Literature 132(2), 209-227. http://dx.doi.org/10.1353/jbl.2013.0025

Levirate Marriage, n.d., viewed 14 December 2008, from http://scriptures.Ids.org/ $\mathrm{bd} / \mathrm{l} / 25$ ?sr $=1$

Lloyd, P.C., 1959, 'Some notes on the Yoruba rules of succession and on "family property"', Journal of African Law 3(1), 7-32. http://dx.doi.org/10.1017/\$0021855300005696

Miller, J.E., n.d., 'Procreation values: Polygamy and levirate marriage', viewed 21 Apri 2010, from http:othershepherd.org/miller_10_polygamy_Marriage_sex_and_Bible. pdf

Muldoon, D.K., n.d., Levirate Marriage, viewed 03 December 2012, from http://www. pceasydney.org.au/sermons/Levirate_Marriage.pdf

Niditch, S., 1979, 'The wronged woman righted: An analysis of Genesis 38', The Harvard Theological Review 72(1/2), 143-149.

Nwaoru, E.O., 2002, 'Primogeniture in the Old Testament and reversed rights of succession', The Nigerian Journal of Theology 16, 74-89.

Okeke, P.E., 2000, 'Reconfiguring tradition: Women's rights and social status in contemporary Nigeria', Africa Today 47(1), 49-63. http://dx.doi.org/10.1353/ at.2000.0018

Oladosu, O.A., 2008, 'The challenge of modernity to the practice of circumcision in Islam, Christianity and Africa Traditional Religion among the Ife people', M.A. dissertation, Department of Religious Studies, Obafemi Awoloeo University, lle-Ife.

Phillips, A., 1973, 'Some aspects of family law in pre-exilic Israel', Vetus Testamentum 23(3), 349-361

Porter, J.R., 1965, 'The legal aspects of the concept of "corporate personality" in the Old Testament', Vetus Testamentum 15(3), 361-380.

Potash, B., (ed.), 1986, Widows in African societies: Choices and constraint, Stanford University Press, Stanford.

Satlow, M.L., n.d., 'Jewish marriage in antiquity', $\mathrm{H}$ - Net Reviews in the Humanities and Social Sciences, viewed 03 December 2012, from http://www.h-net.org/reviews/ showrev.php,9016

Siquans, A., 2009, 'Foreigness and poverty in the case of Ruth: A legal way for a poor foreign woman to be integrated into Israel', Journal of Biblical Literature 128(3), 443-452.

Struensee, V.V., n.d., 'Widows, aids, health and human rights in Africa', viewed 11 December 2012, from http://liphea.halliance.org/featurepresentationpages/jameskey-transformational stewardship/additional-readings-and-websites/documentsandresources/WIDOWS,\%20AIDS_\%2OHEALTH\%20AND\%20HUMAN\%20RIGHTS\%20 IN\%20AFRICA.pdf

The New Encyclopedia of Judaism, n.d., viewed 16 December 2008, from http://www. answers.com/topic/levirate-marriage-1

The Shepherd, 2000, The Shepherd: An Orthodox Christian Pastoral Magazine Xxi(4) viewed 30 April 2010, from http://www.saintedwardbrotherhood.org/2000/ shepherd_December_2008_B.pdf

Weisberg, D.E., 2008, Levirate marriage and the family in ancient Judaism, University Press, England.

Wilson, A., n.d. 'Sermon on Genesis 38: An exposition of Genesis', viewed 21 April 2010, from http://www.gracepcanh.org/files/Gen38WEB.pdf 